\title{
PENGARUH VARIABILITAS PERSEDIAAN, UKURAN PERUSAHAAN DAN INTENSITAS PERSEDIAAN TERHADAP PEMILIHAN METODE PENILAIAN PERSEDIAAN \\ (Studi Empiris Perusahaan Manufaktur Di Bursa Efek Indonesia Tahun 2014-2017)
}

\author{
Erwin Febriansyah, Ade Tiara Yulinda, Lina Rosalinda \\ Program Studi Akuntansi Fakultas Ekonomi Universitas Muhammadiyah Bengkulu \\ Program Studi Manajemen Fakultas Ekonomi Universitas Muhammadiyah Bengkulu \\ erwinfebriansyah@gmail.com, ade91tiarayulinda@gmail.com, Lina23rosalinda@gmail.com
}

\begin{abstract}
ABSTRAK
Erwin Febriansyah, Ade Tiara Yulinda, Lina Rosalinda; Penelitian ini bertujuan untuk mengetahui pengaruh variabilitas persedian, ukuran perusahaan dan intensitas persediaan terhadap pemilihan metode penilaian persediaan. Penelitian ini meneliti 3 variabel independen yaitu variabilitas persediaan, ukuran perusahaan dan intensitas persediaan. Sedangkan variabel dependen dalam penelitian ini adalah metode FIFO dan metode average. Jenis penelitian kuantitatif, data yang digunakan data sekunder. Populasi penelitian seluruh perusahaan manufaktur yang terdaftar di BEI tahun 2014-2017.

Teknik pengambilan sampel menggunakan purposive sampling, dengan kriteria-kriteria dan terpilih 41 perusahaan unit analisis menjadi sampel dan dikali jumlah periode tahun pengamatan (time series), sebanyak 164 sampel (41 perusahaan x 4 tahun). Metode analisis data menggunakan regresi logistik menggunakan SPSS 18.0.

Ada 4 hipotesis penelitian, menguji pengaruh variabilitas persediaan, ukuran perusahaan, ,intensitas persediaan terhadap pemilihan metode penilaian persediaan dan Menguji variabilitas persediaan, ukuran perusahaan, dan itensitas persediaan secara simultan berpengaruh terhadap pemilihan metode penilaian persediaan. Hasil menunjukan : 1) Variabilitas persediaan tidak berpengaruh terhadap pemilihan metode penilaian persediaan. 2) Ukuran perusahaan tidak berpengaruh terhadap pemilihan metode penilaian persediaan. 3) Intensitas persediaan berpengaruh terhadap pemilihan metode penilaian persediaan. 4) variabilitas persediaan, ukuran perusahaan, dan itensitas persediaan berpengaruh secara simultan terhadap pemilihan metode penilaian persediaan
\end{abstract}

\begin{abstract}
Erwin Febriansyah, Ade Tiara Yulinda, Lina Rosalinda; This study purposes to determine the effect of inventory variability and intensity, company size, on the selection of inventory assessment method. This research examined four independent variables namely inventory variability and intensity, companies size, its dependent variable was the FIFO method and the average method. Type of this research was quantitative research by using secondary data. Research population was all manufacturing companies listed on the Indonesia Stock Exchange of the 2014-2017. The sampling technique used purposive sample, with criteria and selected 41 unit analysis companies to be samples and multiplied by the number observation period are obtained 164 samples (41 companies $x$ 4year). The method for data analysis used logistic regression by using SPSS 18.0. There were four research hypotheses; to examine the effect of inventory variability and intensity, companies size on the selection of inventory assessment methods. The result of study showed that inventory variability, companies size, do not affect on the selection of inventory valuation method. Meanwhile, intensity inventory affects the selection of inventory valuation methods and inventory variability and intensity, companies size together influence the selection of inventory valuation methods.
\end{abstract}

Keywords: Inventory Variability, Company Size, Inventory Intensity, FIFO, Average

\section{Latar Belakang}

Menurut Pernyataan Standar Akuntansi Keuangan (PSAK) No. 14 (revisi 2008) persediaan sebagai asset yang; (i) tersedia untuk dijual dalam kegiatan usaha biasa; (ii) dalam proses produksi untuk penjualan tersebut; (iii) dalam bentuk bahan atau perlengkapan untuk digunakan dalam proses produksi atau pemberian jasa. 
Pada dasarnya persediaan mempermudah atau memperlancar jalannya operasi perusahaan yang dilakukan secara berturut-turut untuk memproduksi barang-barang serta menyampaikan kepada pelanggan.

Sebelum dilakukannya revisi PSAK 14 (2008) terdapat 3 metode akuntansi persediaan yang diakui, yaitu FIFO, LIFO, dan Metode rata-rata (weighted average) setelah adanya revisi, metode akuntansi yang diakui hanya FIFO dan weighted average. Dengan kata lain, metode LIFO sudah tidak diakui di PSAK 14 (revisi 2008). PSAK 14 (revisi 2008) ini didasari oleh peraturan perpajakan di Indonesia. Dapat dikatakan demikian karena peraturan perpajakan juga tidak memperbolehkan penggunaan metode LIFO. Peraturan perpajakan ini tertuang dalam Undang-Undang No.36 Tahun 2008. Dalam dunia perpajakan, metode LIFO dianggap hanya membuat kerugian bagi negara karena dengan menggunakan metode ini, laba yang dihasilkan akan semakin kecil yang berakibat pajak yang dibayarkan juga akan semakin kecil. Hal ini menjadi jalan bagi perusahaan-perusahaan yang ingin memperkecil beban pajaknya. Oleh karena itu, metode LIFO tidak diperbolehkan lagi untuk digunakan dalam peraturan perpajakan di Indonesia.

Informasi mengenai persediaan dan setiap persediaan pada akun persediaan sangat diperlukan investor, manajer dan pemerintah karena berpengaruh signifikan terhadap operasional perusahaan. Indikasi ini menunjukan luasnya peranan persediaan dalam menentukan laba perusahaan dan pajak yang harus dibayarkan. Penerapan metode akuntansi yang berbeda akan menimbulkan dampak yang berbeda pula.

\section{LANDASAN TEORI}

\section{Hubungan Variabilitas Persediaan Terhadap Pemilihan Metode Penilaian Persediaan}

Variabilitas persediaan merupakan variasi dari nilai persediaan dan menggambarkan operasional perusahaan yang mencerminkan teknik persediaan dan akuntansi persediaan serta pergerakanpergerakan persediaan itu sendiri (Kukuh Setiyanto, 2012). Apabila variasi persediaan semakin besar maka laba sebuah perusahaan juga akan besar begitu pula sebaliknya apabila semakin kecil variasi nilai persediaan maka variasi terhadap labanya juga akan semakin kecil. Semakin tinggi variasi nilai persediaan maka perusahaan akan menggunakan FIFO sehingga laba yang dihasilkan lebih besar dan tidak bisa melakukan tax saving sedangkan semakin rendah variasi nilai persediaan maka perusahaan akan memilih rata-rata sehingga laba yang dihasilkan kecil sehingga dapat melakukan tax saving. Hal ini didukung penelitian Siti Sangadah (2014) dan Brian Syailendra (2014) Tutuk Mahardika, (2017) menunjukkan bahwa variabel variabilitas persediaan berpengaruh terhadap pemilihan metode akuntansi persediaan.

\section{Hubungan Ukuran Perusahaan Terhadap Pemilihan Metode Penilaian Persediaan}

Ukuran perusahaan perusahaan pencapaian operasi lancar dan pengendalian persediaan (Siti Sangadah, 2014). Perusahaan besar cenderung memilih metode rata-rata karena biaya pajak yang dibayarkan relatif lebih kecil dibandingkan ketika perusahaan menggunakan metode FIFO. Penggunaan metode rata-rata selain bisa memperoleh penghematan pajak, juga bisa menghindari political cost atau biaya politis (Riswan, 2016). Semakin besar ukuran perusahaan, maka perusahaan akan memilih metode rata-rata yang dapat menurunkan laba sehingga perusahaan bisa melakukan tax saving dan menghindarkan perusahaan dari biaya politik, sedangkan untuk perusahaan kecil perusahaan akan memilih metode yang dapat menaikkan laba yaitu metode FIFO untuk dapat memperoleh pinjaman dari bank karena bank menilai kinerja perusahaan melalui laba yang dihasilkan (Riswan, 2016). Hal ini didukung dengan penelitian Linda santioso (2013) dan Tutuk Mahardika (2017) menunjukkan bahwa variabel ukuran perusahaan berpengaruh positif terhadap pemilihan metode akuntansi persediaan. Berdasarkan uraian tersebut menunjukkan bahwa variabel ukuran perusahaan berpengaruh terhadap pemilihan metode akuntansi persediaan.

\section{Hubungan Intensitas Persediaan Terhadap Pemilihan Metode Penilaian Persediaan}

Intensitas persediaan atau rasio perputaran persediaan (inventory turnover atau stock turnover) adalah ukuran seberapa sering persediaan barang dagang terjual dalam waktu satu periode. Intensitas persediaan yang tinggi rnenunjukkan jumlah penjualan pada perusahaan tersebut tinggi dan menghasilkan laba yang tinggi. Sebaliknya, rasio perputaran persediaan yang rendah rnenunjukkan jumlah penjualan pada perusahaan tersebut rendah dan rnanghasilkan laba yang rendah. Tinggi rendahya laba yang akan dihasilkan tergantung dari metode penilaian yang akan digunakan Brian Syailendra, (2014). Hal ini didukung dengan penelitian Linda Santioso dan Stella Halim (2013) mengemukakan bahwa intensitas persediaan mempunyai pengaruh signifikan terhadap pemilihan metode akuntansi 
persediaan. hal tersebut menunjukkan bahwa variabel intensitas persediaan berpengaruh terhadap pemilihan metode akuntansi persediaan.

\section{Hubungan Variabilitas Persediaan, Ukuran Perusahaan, Dan Itensitas Persediaan Terhadap Pemilihan Metode Penilaian Persediaan}

Faktor yang dapat mempengaruhi pemilihan metode penilaian persediaan, antara lain variabilitas persediaan merupakan variasi dari nilai persediaan suatu perusahaan (Brian Syailendra, 2014). Ukuran perusahaan dapat diartikan besar kecilnya suatu perusahaan yang dapat dinyatakan dengan total aktiva (Riswan, 2016). intensitas persediaan/perputaran persediaan (inventory turnover ratio) merupakan salah satu rasio aktivitas (Hendra, 2009) Rasio ini mengukur kemampuan perusahaan dalam menjual produknya dalam suatu periode tertentu dibandingkan dengan jumlah persediaan yang dimiliki. Faktor-faktor tersebut secara bersama-sama memiliki hubungan yang kuat yang mempengaruhi perusahaan dalam memilih metode penilaian persediaan. Berdasarkan uraian tersebut, diduga terdapat hubungan yang positif antara pengaruh variabilitas persediaan, ukuran perusahaan dan intensitas persediaan terhadap pemilihan metode penilaian persediaan.

\section{KERANGKA PENELITIAN}

Gambar 1

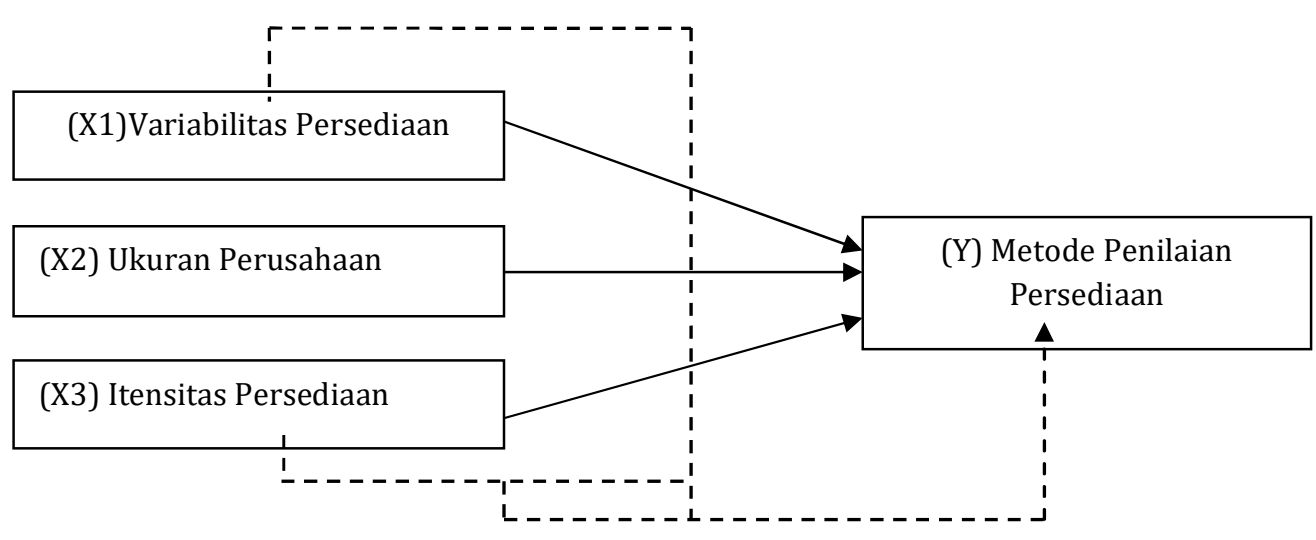

Gambar 1. Kerangka Penelitian

\section{METODOLOGI}

\section{Jenis Penelitian dan Teknik Pengumpulan Data}

jenis penelitian kuantitatif. Menurut Sugiyono (2014) "Penelitian kuantitatif adalah metode ilmiah/scientific karena telah memenuhi kaidah-kaidah ilmiah yaitu, konkrit/empiris, obyektif, terukur, rasional, dan sistematis". Metode ini disebut kuantitatif karena data penelitian berupa angka-angka dan analisis mengunakan statistik.

Dalam penelitian ini menggunakan pengujian hipotesis dengan analisis regresi logistik. Analisis regresi logistik merupakan alat analisis yang digunakan untuk mengukur seberapa jauh pengaruh variabel independen terhadap variabel dependen, dalam hal ini variabel dependennya dalam bentuk variabel dummy (diantara 0 dan 1). Dalam analisis regresi logistik tidak memerlukan uji asumsi normality multivariate dan homoskedastisitas karena didalam analisis regresi logistik dihasilkan suatu analisis model fit yang menggambarkan apakah data dari penelitian ini baik untuk digunakan dalam penelitian (Ghozali, 2015)

\section{HASIL PENELITIAN DAN PEMBAHASAN Hasil Uji Statistik Deskriptif}

Tabel 1 menggambarkan mengenai statistik deskriptif seluruh variabel dalam penelitian ini. Nilai minimum menggambarkan nilai terkecil yang merupakan hasil dari pengolahan data sampel. Nilai maksimum merupakan nilai terbesar yang berasal dari analisis data. Mean adalah nilai rata-rata yang menggambarkan jumlah data dibandingkan dengan banyaknya jumlah masing-masing variabel. Sedangkan standar deviasi adalah hasil pengukuran yang menjelaskan penyebaran distribusi maupun variabilitas yang terdapat pada data. 
Tabel 1. Hasil Uji Statistik Deskritif

\begin{tabular}{|l|r|r|r|r|r|}
\hline & \multicolumn{1}{|c|}{$\mathrm{N}$} & \multicolumn{1}{c|}{ Minimum } & Maximum & \multicolumn{1}{c|}{ Mean } & \multicolumn{1}{c|}{ Std. Deviation } \\
\hline Variabilitas Persediaan & 164 & .05 & 9.57 & 2.8539 & 2.07320 \\
Ukuran Perusahaan & 164 & 23.78 & 31.52 & 28.2593 & 1.53331 \\
Intensitas Persediaan & 164 & 1.67 & 70.06 & 23.6710 & 14.78327 \\
Metode persediaan & 164 & 0 & 1 & .80 & .398 \\
Valid N (listwise) & 164 & & & & \\
\hline
\end{tabular}

Sumber: data sekunder diolah 2019

Berdasarkan tabel 1 nilai statistik deskriptif untuk variabel variabilitas persediaan nilai terendah (minimum) sebesar 0.05. Nilai tertinggi (maximum) sebesar 9.57. Sedangkan nilai rata-rata sebesar 2.8539 dan standar deviasi 2.07320. Mean memiliki nilai lebih besar daripada standar deviasi yaitu $2.8539>2.07320$, itu artinya sampel yang dimiliki besarnya hampir sama antar masing-masing sampel perusahaan (tidak variatif).

Nilai terendah (minimum) ukuran perusahaan sebesar 23.78 Nilai tertinggi (maximum) sebesar 31.52. Sedangkan nilai rata-rata sebesar 28.2593 dan standar deviasi 1.53331 . Mean memiliki nilai 28.2593 lebih besar daripada standar deviasi yaitu 1.53331, itu artinya sampel yang dimiliki besarnya hampir sama antar masing-masing sampel perusahaan (tidak variatif).

Nilai terendah (minimum) intensitas persediaan sebesar 1.67. Nilai tertinggi (maximum) sebesar 70.06. Sedangkan nilai rata-rata sebesar 23.6710 dan standar deviasi 14.78327. Mean memiliki nilai lebih besar daripada standar deviasi yaitu $23.6710>14.78327$, itu artinya sampel yang dimiliki besarnya hampir sama antar masing-masing sampel perusahaan (tidak variatif).

\section{Uji Kelayakan Model Regresi Logistik Uji Nilai -2 Log Likelihood}

Kelayakan model regresi dinilai dengan menggunakan Uji Nilai -2 Log Likelihood Pengujian ini dilakukan untuk mengetahui apakah model fit dengan data baik sebelum maupun sesudah variabel bebas dimasukkan ke dalam model. Pengujian dilakukan dengan membandingkan nilai antara -2Log Likelihood $(-2 L L)$ pada awal (Block Number $=0$ ) dengan nilai -2Log Likelihood (-2LL) pada akhir (Block Number $=1$ ). Adanya pengurangan nilai antara -2Log Likelihood (-2LL) awal dengan -2Log Likelihood (-2LL) akhir menunjukkan bahwa model yang dihipotesiskan fit dengan data.

Tabel 2. Uji Nilai -2 Log Likelihood

\begin{tabular}{|c|c|c|c|c|}
\hline \multirow[t]{2}{*}{ Iteration } & & \multirow[b]{2}{*}{-2 Log likelihood } & \multicolumn{2}{|c|}{ Coefficients } \\
\hline & & & Constan & \\
\hline \multirow[t]{4}{*}{ Step 0} & 1 & 162.935 & & 1.220 \\
\hline & 2 & 161.892 & & 1.406 \\
\hline & 3 & 161.889 & & 1.417 \\
\hline & 4 & 161.889 & & 1.417 \\
\hline
\end{tabular}

Sumber: data sekunder diolah 2019

Tabel 3. Uji Nilai -2 Log Likelihood

(Block Number =1)

Iteration Historya,b,c

\begin{tabular}{|c|c|c|c|c|c|}
\hline \multirow[t]{2}{*}{ Iteration } & \multirow{2}{*}{$\begin{array}{c}-2 \text { Log } \\
\text { likelihood } \\
\end{array}$} & \multicolumn{4}{|c|}{ Coefficients } \\
\hline & & Constant & VarPers & UkPeru & InPers \\
\hline Step 11 & 153.162 & -1.665 & -.153 & .096 & .025 \\
\hline 2 & 149.546 & -2.735 & -.215 & .136 & .043 \\
\hline 3 & 149.377 & -2.935 & -.230 & . 141 & .049 \\
\hline 4 & 149.376 & -2.938 & -.232 & .141 & .050 \\
\hline 5 & 149.376 & -2.938 & -.232 & .141 & .050 \\
\hline
\end{tabular}

Sumber: data sekunder diolah 2019 
Pada tabel di atas menunjukkan bahwa nilai -2 Log Likelihood awal pada block 0 adalah sebesar 161.889 dan nilai -2 Log Likelihood akhir pada block 1 adalah sebesar 149.376 Sehingga dapat diketahui bahwa nilai -2 Log Likelihood akhir lebih kecil dari nilai -2 Log Likelihood awal dengan adanya penurunan sebesar 12.513 yang mengindikasikan bahwa model fit dengan data atau model dapat diterima karena cocok dengan data observasinya.

\section{Uji Koefisien Determinasi (Nagelkerke's R Square)}

Tabel 4. Model Summary

\begin{tabular}{|l|r|r|r|}
\hline Step & -2 Log likelihood & Cox \& Snell R Square & Nagelkerke R Square \\
\hline 1 & $149.376 \mathrm{a}$ & .073 & .117 \\
\hline
\end{tabular}

Tabel di atas menunjukkan nilai Nagelkerke $R$ Square sebesar 0.117 Hal ini mengandung arti bahwa variabel dependen yaitu metode akuntansi persediaan dipengaruhi sebesar $11.7 \%$ oleh variabel independennya yaitu variabilitas persediaan, ukuran perusahaan dan intensitas persediaan sedangkan sisanya sebesar $88,3 \%$ dijelaskan oleh variabel lain yang tidak masuk dalam penelitian.

\section{Uji Hosmer And Lemeshow Test}

Tabel 5. Uji Hosmer And Lemeshow Test

\begin{tabular}{|l|r|r|r|}
\hline Step & Chi-square & Df & \multicolumn{2}{|c|}{ Sig. } \\
\hline 1 & 13.065 & & .110 \\
\hline
\end{tabular}

Berdasarkan pengujian Hosmer and Lemeshow Test untuk menguji kelayakan model yang tersaji pada tabel di atas didapatkan nilai signifikansi 0.110 yang nilainya diatas 0.05 . Dengan demikian hipotesis diterima yang berarti tidak ada perbedaan yang signifikan antara model dengan nilai observasinya sehingga model dapat dikatakan fit.

\section{Hasil Uji Regresi Logistik Uji Parsial}

Tabel 6. Variables in the Equation

\begin{tabular}{|c|c|c|c|c|c|c|c|c|c|}
\hline & \multirow[b]{2}{*}{ B } & \multirow[b]{2}{*}{ S.E. } & \multirow[b]{2}{*}{ Wald } & \multirow[b]{2}{*}{$\mathrm{df}$} & \multirow[b]{2}{*}{ Sig. } & \multirow[b]{2}{*}{$\operatorname{Exp}(B)$} & \multicolumn{2}{|c|}{ 95\% C.I.for EXP(B) } \\
\hline & & & & & & & & Lower & Upper \\
\hline \multirow[t]{4}{*}{ Step $1^{\mathrm{a}}$} & VarPers & -.232 & .122 & 3.596 & 1 & .058 & .793 & .625 & 1.008 \\
\hline & UkPeru & .141 & .164 & .742 & 1 & .389 & 1.152 & .835 & 1.589 \\
\hline & InPers & .050 & .023 & 4.579 & 1 & .032 & 1.051 & 1.004 & 1.100 \\
\hline & Constant & -2.938 & 4.543 & .418 & 1 & .518 & .053 & & \\
\hline
\end{tabular}

Sumber: data sekunder diolah 2019

Berdasarkan hasil analisis dengan menggunakan regresi logistik, maka diperoleh persamaan regresi sebagai berikut:

$$
\begin{aligned}
& \operatorname{Ln} \frac{p}{1-p}=\beta+\beta 1 \text { VarPers }+\beta 2 \text { UkPeru }+\beta 3 \text { InPers }+\mathrm{e} \\
& \operatorname{Ln} \frac{p}{1-p}=-2.938-0.232+0.141+0.050
\end{aligned}
$$

\section{Uji Simultan}

\begin{tabular}{|c|c|c|c|c|}
\hline & & Chi-square & Df & Sig. \\
\hline \multirow{3}{*}{$\begin{array}{l}\text { Step } \\
1\end{array}$} & Step & 12.513 & 3 & .006 \\
\hline & Block & 12.513 & 3 & .006 \\
\hline & Model & 12.513 & 3 & .006 \\
\hline
\end{tabular}

Tabel 7. Omnibus Tests of Model Coefficients

Sumber: data sekunder diolah 2019 
Berdasarkan hasil Omnibust Test of Model Coefficient yang disajikan pada tabel di atas diperoleh nilai signifikansi sebesar 0,006dimana nilai 0,006 lebih kecil dari 0,05 sehingga menunjukkan bahwa data dalam penelitian ini layak untuk digunakan dan penggunaan variabel independen dalam model penelitian ini secara simultan dapat memprediksi variabel dependennya.

\section{Pembahasan}

Pengaruh Variabilitas Persediaan Terhadap Pemilihan Metode Penilaian Persediaan

Hasil penelitian ini memberikan bukti bahwa variabilitas persediaan tidak berpengaruh terhadap pemilihan metode penilaian persediaan, dimana variabel variabilitas persediaan mempunyai tingkat signifikan sebesar 0,058 dan beta -0.232. Berarti tingkat signifikan lebih kecil dari 0,05 (0,058> $0,05)$ hasil pengujian hipotesis tersebut menunjukan bahwa variabilitas persediaan tidak berpengaruh terhadap pemilihan metode penilaian persediaan.

Hasil penelitian ini tidak konsisten dengan penelitian sebelumnya yang pernah dilakukan oleh Syailendra (2013), Sangadah (2014), yang menyatakan bahwa variabiltas persediaan berpengaruh signifikan terhadap pemilihan metode akuntansi persediaan. Tetapi Hasil penelitian ini konsisten dengan penelitian sebelumnya yang dilakukan Tutuk Mahardika, Hj, Anik Malikah dan Arifudi (2017) Alika Lathifa Hanum (2017) bahwa variabilitas persediaan tidak berpengaruh terhadap pemilihan metode penilaian persediaan.

Pada dasarnya metode average merupakan kompromi antara metode FIFO dan metode LIFO, dimana pengaruh dalam menghitung harga pokok penjualan dan nilai persediaan akhir cenderung diambil rata-ratanya. Sehingga penggunaan metode rata-rata tidak terlalu berpengaruh dalam perhitungan persediaan akhir, Carl S.Warren, dkk (2014), sedangkan sampel dalam penelitian ini sebagian besar perusahaan menggunakan metode average. Sehingga kurangnya variasi sampel dalam penggunaan metode penilaian persediaan, menjadi variabel ini tidak berpengaruh terhadap metode penilaian persediaan.

\section{Pengaruh Ukuran Perusahaan Terhadap Pemilihan Metode Penilaian Persediaan}

Hasil pengujian menunjukan bahwa ukuran perusahaan tidak berpengaruh signifikan terhadap pemilihan metode penilaian persediaan. Ukuran perusahaan memiliki nilai signifikan (0.480) yang berarti tingkat signifikan ukuran perusahaan $>0.05$. Nilai tersebut membuktikan bahwa ukuran perusahaan tidak memiliki pengaruh signifikan terhadap pemilihan metode penilaian persediaan. Dengan demikian tidak semua perusahaan besar menggunakan metode penilaian persediaan average dan tidak semua perusahaan kecil menggunakan metode penilaian persediaan FIFO, Alika Lathifa Hanum (2017).

Didalam penelitian ini perusahaan besar juga cenderung menggunakan metode penilaian persediaan FIFO. Hal ini dapat terjadi karena setiap perusahaan memiliki tujuan yang berbeda, dimana ada perusahaan yang memiliki tujuan memiliki laba tinggi agar mendapatkan dana dari investor atau tujuan mengurangi beban pajak yang harus dibayarkan.

Perusahaan yang digunakan dalam penelitian ini adalah tergolong perusahaan besar yang cenderungan untuk menggunakan metode average agar laba perusahaan terlihat tidak setinggi jika menggunakan metode FIFO. Sehingga pajak yang dibayarkan juga rendah. Hal inilah yang menguatkan bahwa metode average banyak digunakan oleh perusahaan manufaktur yang ada di Indonesia. Hal ini sejalan dengan penelitian yang dilakukan oleh Alika Latifa Hanum (2016) dan Sangadah dan Kusmuriyanto (2014) yang tidak menemukan adanya pengaruh ukuran perusahaan terhadap pemilihan metode akuntansi persediaan.

\section{Pengaruh Intensitas Persediaan Terhadap Pemilihan Metode Penilaian Persediaan}

Hasil penelitian menunjukan bahwa intensitas persediaan berpengaruh signifikan terhadap pemilihan metode penilaian persediaan. intensitas persediaanmemiliki nilai signifikan (0.033) yang berarti tingkat signifikan intensitas persediaan $<0.05$. Nilai tersebut membuktikan H3 diterima, bahwa intensitas persediaan memiliki pengaruh signifikan terhadap pemilihan metode penilaian persediaan. Hasil penelitian ini konsisten dengan hasil penelitian sebelumnya yang dilakukan oleh Maharani (2014) dan Sri Ayem, dkk (2018) yang menyatakan intensitas persediaan berpengaruh secara signifikan terhadap pemilihan metode persediaan.

\section{Pengaruh Variabilitas Persediaan, Ukuran Perusahaan, Dan Itensitas Persediaan Terhadap Pemilihan Metode Penilaian Persediaan}

Hasil pengujian hipotesis empat bahwa variabilitas persediaan, ukuran perusahaan dan intensitas persediaan berpengaruh secara simultan terhadap pemilihan metode penilaian persediaan diperoleh nilai signifikansi sebesar 0,006 dimana nilai 0,006 < dari 0,05. Hasil penelitian ini konsisten 
dengan hasil penelitian Rudy Mahardika, Elva dan Purweni Widhianningrum (2015) dan Tutuk Mahardika, Hj, Anik Malikah dan Arifudi (2017).

Variabilitas persediaan, ukuran perusahaan dan intensitas persediaan berpengaruh secara bersama-sama dapat mempengaruhi pemilihan metode penilaian persediaan.

\section{KESIMPULAN}

1. Variabilitas persedian tidak berpengaruh terhadap pemilihan metode penilaian persediaan.

2. Ukuran perusahaan tidak berpengaruh terhadap pemilihan metode penilaian persediaan.

3. Intensitas persediaan berpengaruh terhadap pemilihan metode penilaian persediaan.

4. variabilitas persediaan, ukuran perusahaan dan intensitas persediaan diuji secara bersama-sama atau simultan, hasil pengujian menunjukkan bahwa ketiga variabel tersebut berpengaruh signifikan secara simultan terhadap pemilihan metode penilaian persediaan. Hal ini menunjukan bahwa ketiga variabel tersebut memiliki peranan penting dalam menentukan metode penilaian persediaan.

\section{SARAN}

1. Untuk peneliti selanjutnya diharapkan dapat meneliti tidak hanya data perusahaan manufaktur saja.

2. Untuk penelitian selanjutnya diharapkan memperpanjang periode waktu penelitian (time series).

3. Menambah variabel selain variabel dependen atau independen yang digunakan dalam penelitian ini seperti variabel moderating, variabel intervening dan variabel control untuk melakukan analisis lebih mendalam lagi mengenai variabel yang mempengaruhi pemilihan metode penilaian persediaan.

\section{DAFTAR PUSTAKA}

Ghozali, Imam. 2013. “Aplikasi Analisis Multivariate Dengan Program SPSS”. Semarang: Badan Penerbit Universitas Diponegoro. Edisi 7

Harahap, r, k., \& Jiana, d. m. (2009). "Analisis Factor-Fakor Yang Berpengaruh Terhadap Pemilihan Metode Akuntansi Persediaan Pada Peruahaan Manufaktur Di Bursa Efek Jakarta”. Media Riset Akuntansi, Auditing Dan Informasi, Vol. 9, No. 3. Ikatan Akuntansi Indonesia.

Hutahean, Threysa Memoriana, Iskandar muda. 2014 "Pengaruh ukuran perusahaan, variabilitas persediaan, variablitas harga pokok penjualan, laba sebelum pajak, dan fibancial leverage terhadap pemilihan metode akuntansi persediaan pada perusahaan manufaktur, fakultas ekonomi universitas Sumatra utara.

Kasmir, 2011. Analisis Laporan Keuangan. Jakarta: PT Raja Grafindo Persada.

Lupiyoadi, Rambat dan Ridho Bramulya ikhsan,2015 “Praktikum Metode Riset Bisnis" Yogyakarta. Salemba Empat.

Mahardika, Rudy dkk. 2015. “Analisis Faktor-Faktor yang Berpengaruh terhadap Pemilihan Metode Akuntansi Persediaan (Studi pada Perusahaan Manufaktur yang Terdaftar di Bursa Efek Indonesia)". Jurnal Akuntansi dan Pendidikan, Vol. 4 No. 2, IKIP PGRI Madiun.

Mahardika, Tutuk dkk. 2017. "Analisis Pengaruh Ukuran Perusahaan, Variabilitas Persediaan, Variabilitas Harga Pokok Penjualan, Rasio Perputaran Persediaan dan Margin Laba Kotor Terhadap Pemilihan Metod e Akuntansi Persediaan”. Fakultas Ekonomi Universitas Islam Malang: Malang.

Martini Dwi dkk. 2016 "Akuntansi Keuangan Menengah Berbasis PSAK” Edisi 2 buku 1, Jakarta: Badan penerbit salemba empat.

Pengertian manufaktur

http://www.pengertianku.net.2017/01/pengertian-manufaktur-dan-contohnya.html diakses pada hari: Senin, 04 desember 2018.

Riswan, Restiani fasa (2016). "Analisis Faktor-faktor Yang Mempengaruhi Pemilihan Metode Penilaian Persediaan Pada Perusahaan Dagang Yang Terdaftar Di Bursa Efek Indonesia Periode 2010-204", Jurnal akuntansi \& keuangan, Vol 7, no. 2 Hal 192-210.

Riyanto, Bambang. 2010. “Dasar-dasar pembelajaran perusahaan”. Fakultas Ekonomi dan Bisnis. Penerbit Universitas Gajah Mada (UGM).

Rudianto. 2012. "Pengantar akuntansi". Jakarta: Erlangga

S.warren, Carl dkk. 2014. "Pengantar Akuntansi Adaptasi Indonesia". Edisi 25. Jakarta: Salemba Empat.

Sangadah, Siti dan Kusmuriyanto. 2014. "Analisis Pemilihan Metode Akuntansi Persediaan Pada Perusahaan Manufaktur”. Accounting Analysis Journal (AAJ), Vol.3, No.3, ISSN: 22526765. 
Santioso, Linda dan Stella Halim. 2013. "Struktur Kepemilikan Dan Rasio Perputaran Persediaan Terhadap Pemilihan Metode Persediaan". Fakultas Ekonomi Universitas Tarumanagara, vol 13, No. 2 Hal $945-970$.

Ayem, Sri dkk .2018. "Pengaruh Ukuran Perusahaan, variabilitas Persediaan, Kepemilikan manajerial, Financial Leverage Dan Laba Sebelum Pajak Terhadap Pemilihan Metode Akuntansi Persediaan (Studi Empiris Pada Perusahaan Sub Sektor Farmasi Yang Terdaftar Di Bursa Efek Indonesia Periode 2012-2016)". Jurnal. ustjogja.ac.id, Vol. 2, No. 1.

Sugiyono. 2014. "Metode Penelitian Kuantitatif, Kualitatif dan R\&D”. Bandung: Alfabeta.

Syailendra, Brian dan Raharja. 2014. "Analisis Faktor-Faktor Yang Berpengaruh Terhadap Pemilihan Metode Penilaian Persediaan (Studi Kasus Pada Perusahaan Dagang Dan Manufaktur Yang Terdaftar Di BEI Tahun 2008-2012)”, Diponegoro Journal of Accounting, Volume 3 Nomor 2, Hal. $1-12$.

Victoria, Nancy. 2016. "Faktor Ukuran Perusahaan, Variabilitas Persediaan, Struktur Kepemilikan, Financial Leverage, Dan Rasio Lancar Dalam Pemilihan Metode Akuntansi Persediaan Pada Subsector Farmasi Yang Terdaftar Di BEI". Jurnal FinAcc, Vol 1, No 7.

Yusuf, Muhammad dkk (2017). "Analysis Of Effect Of Ownership Structure, Company Size, Profit Before Tax ,Laverage Ratio And Current Ratio Selection Of Accounting Method Supplies Industry Sector In Basic And Chemical Listed In Bei 2013-2016". Universitas Pandanaran Semarang.

http://www.idx.co.id/

http://www.sahamok.com/ 